\title{
SUSPENSÃO DA EXECUÇÃO DE LEI DECLARADA INCONSTITUCIONAL: análise do comportamento do Supremo Tribunal Federal e Senado no período pós-1988
}

\section{Antonio Eduardo Reichmann Seixas ${ }^{7}$}

\section{Palavras-Chave}

controle de constitucionalidade / controle difuso / Senado Federal / Supremo Tribunal Federal

\section{SUMÁRIO}

1. Introdução. 2. Questões dogmáticas. 2.1. Natureza política do ato do Senado. 2.2. Ausência de prazo para decisão. 2.3. Possibilidade de recusa parcial ou integral da suspensão da execução da lei. 2.4. Impossibilidade de revogação da Resolução do Senado. 2.5. Efeitos temporais da Resolução do Senado. 2.6. Conclusões preliminares. 3. Pesquisa empírica. 3.1. Apontamentos metodológicos. 3.2. Análise das conclusões já obtidas. 3.3. Análise das comunicações feitas pelo STF. 3.4. Análise das decisões do Senado. 4. Conclusões. 5. Referências.

\section{Resumo}

O sistema brasileiro de controle de constitucionalidade comporta desde 1934 um mecanismo segundo o qual cabe ao Senado suspender a execução de lei declarada inconstitucional por decisão definitiva do Supremo Tribunal Federal. A Constituição de 1988 prevê esse mecanismo mesmo em um cenário diverso do de sua concepção, o que dificulta a compreensão de vários aspectos do instituto. O objetivo deste trabalho é analisar o comportamento de Supremo Tribunal Federal e Senado na matéria no período que vai de outubro de 1988 a novembro de 2016, a partir de um levantamento documental de todas as comunicações entre as instituições no período mencionado. Além disso, empreendeu-se investigação teórica para esclarecer questões dogmáticas deixadas em aberto pela redação do texto constitucional. 


\section{STOP OF APPLICATION OF A LAW DECLARED UNCONSTITUTIONAL: analysis of the brazilian Federal Supreme Court and Federal Senate behavious after 1988}

\section{Antonio Eduardo Reichmann Seixas ${ }^{\top}$}

\section{Keywords}

judicial review / american system / Brazilian Federal Senate / Brazilian Supreme Court

\section{SUMMARY}

1. Introduction. 2. Dogmatic issues. 2.1. Political nature of Senate's act. 2.2. Lack of deadline for decision. 2.3. Possibility of partial or full refusal to suspend the execution of law. 2.4. Impossibility of revocation of Senate Resolution. 2.5. Temporal effects of Senate Resolution. 2.6. Preliminary conclusions. 3. Empirical research. 3.1. Methodological notes. 3.2. Analysis of the partial conclusions. 3.3. Analysis of STF communications. 3.4. Analysis of Senate decisions. 4. Conclusions. 5. References.

\begin{abstract}
Since 1934, the Federal Senate of Brazil has exclusively the competence to stop the application of a law declared unconstitutional by final decision of the Federal Supreme Court. The Constitution of Brazil of 1988 provides this mechanism in a different judicial review system from that of its conception, which makes it difficult to understand some aspects of the institute. The purpose of this article is to analyze the behavior of Federal Supreme Court and the Federal Senate between October 1988 and November 2016, based on a documentary survey of all communications between these institutions. In addition, theoretical research was undertaken to clarify dogmatic questions left open by the constitutional text.
\end{abstract}




\section{INTRODUÇÃO}

Desde 1891, ano de promulgação da primeira Constituição republicana, pratica-se no Brasil o controle difuso, incidental e sucessivo de constitucionalidade. Importado dos sistemas da common law, esse modelo encontrou dificuldades de adaptação ao direito brasileiro, onde não se havia consolidado a regra dos precedentes obrigatórios. Os legisladores pátrios, então, buscaram reiteradamente atenuar as disfunções e incoerências apresentadas pelo sistema adotado.

A primeira medida tomada com esse objetivo data de 1934, quando os constituintes conferiram ao Senado Federal a competência para suspender a execução de "qualquer lei ou ato, deliberação ou regulamento, quando hajam sido declarados inconstitucionais pelo Poder Judiciário". Por meio dessa fórmula, buscou-se aproveitar a todos uma declaração de inconstitucionalidade naturalmente restrita às partes do processo e, assim, evitar a reprodução de demandas ajuizadas por tantos quantos fossem os afetados pelo ato inconstitucional.

O advento da fiscalização abstrata e concentrada de constitucionalidade, em 1965, não impediu a permanência da competência do Senado na matéria. $O$ art. 52, inc. $X$, da Constituição Federal de 1988 prevê que "compete privativamente ao Senado Federal [...] suspender a execução, no todo ou em parte, de lei declarada inconstitucional por decisão definitiva do Supremo Tribunal Federal".

O objetivo do presente trabalho é analisar o instituto no período pós-1988. Para tanto, valeu-se do levantamento documental de todas as comunicações realizadas entre Supremo Tribunal Federal e Senado para fins do art. 52, inc. X, da Constituição no período que vai de outubro de 1988 até novembro de 2016. A metodologia será detalhada no tópico 3.1.

Antes de analisar o comportamento das instituições envolvidas no processo, porém, convém abordar algumas questões dog máticas, tendo em vista a redação simples do dispositivo constitucional e a necessidade do esclarecimento interpretativo de importantes aspectos dessa peculiar forma de atuação do Poder Legislativo no sistema de controle de constitucionalidade.

\section{QUESTÕES DOGMÁTICAS}

A Constituição de 1988 não aborda em detalhes aspectos essenciais da suspensão da execução de lei pelo Senado Federal. Não há, tampouco, lei ordinária que regulamente o instituto. Os regimentos internos de Supremo Tribunal Federal e Senado abordam apenas questões procedimentais ou, então, alguns poucos entendimentos consolidados ao longo do tempo, como o de que o Senado pode suspender apenas as leis declaradas inconstitucionais em controle difuso, uma vez que a fiscalização abstrata e concentrada - de natureza objetiva - por si só já opera com eficácia contra todos².

O Regimento Interno do STF estabelece, em seu art. 178, que a Secretaria Judiciária deve comunicar ao Senado da declaração incidental de inconstitucionalidade logo depois do trânsito em julgado da decisão que a veicula. As cópias do acórdão e do texto da lei cuja execução se deva suspender são então remetidas via ofício assinado pelo Presiden-

\footnotetext{
2 O Supremo Tribunal Federal não divide com outro órgão do Estado a prerrogativa de fulminar de nulidade, num exame geral e abstrato, determinado dispositivo legal por contrariedade à Constituição. Conforme afirmou Ronaldo Poletti (1998, p. 151-152), "a declaração [em controle abstrato], por si só, acarreta a suspensão da execução da lei e nenhuma outra função poderia ter o julgamento, se não essa".
} 
te da corte. Em seguida, o Serviço de Protocolo do Senado recebe essa documentação e a encaminha para leitura em plenário. Uma vez lida, a comunicação segue para a Comissão de Constituição, Justiça e Cidadania (CCJ) que, nos termos do art. 388 do Regimento Interno da casa, formula projeto de Resolução para suspender a execução da lei inconstitucional. Esse projeto é, por fim, apreciado pelo plenário da casa e, se aprovado por maioria de votos, dá origem a Resolução do Senado Federal.

Veja-se que alguns aspectos do dispositivo restam sem o devido esclarecimento, a começar pela própria natureza do instituto. Afinal, o que significa suspender a execução de lei declarada inconstitucional? Tratase de revogar a lei, dar efeitos erga omnes à declaração de inconstitucionalidade ou apenas "dar maior publicidade" à decisão do Supremo? Outras perguntas podem ainda ser formuladas:

1. Recebida a comunicação do Supremo, há prazo legal para que o Senado decida sobre a suspensão da lei declarada inconstitucional? Em caso afirmativo, o que ocorre se esse prazo não for respeitado?

2. O Senado pode se recusar a suspender a execução da lei declarada inconstitucional ou então decidir por suspender apenas parte dela, modulando efeitos?

3. Editada a Resolução do Senado Federal suspendendo a execução de lei, pode o Senado "voltar atrás" e revogar sua própria Resolução?

4. A suspensão da execução da lei opera com eficácia ex tunc ou ex nunc?

As repostas para essas cinco perguntas serão traçadas a seguir, a partir da análise de trabalhos acadêmicos e da jurisprudência do Supremo Tribunal Federal.

\subsection{Natureza política do ato do Senado}

A primeira questão deixada em aberto pelo texto constitucional diz respeito à natureza do ato que suspende a execução de lei declarada inconstitucional. Nesse particular, despontam três entendimentos firmados pela doutrina e pela jurisprudência do STF. O primeiro deles compreende o ato do Senado como mera "republicação" da decisão de inconstitucionalidade, de modo que finalidade seria, portanto, dar maior publicidade à decisão do STF e não se admitiria, por parte do Senado, qualquer possibilidade de emissão de juízo sobre a inconstitucionalidade da lei. Carlos Alberto Lúcio Bittencourt (1968) foi um dos primeiros a defender essa tese, fundamentada na doutrina clássica sobre o ato inconstitucional.

Para essa doutrina, notabilizada pelo Chief Justice da Suprema Corte dos Estados Unidos, John Marshall, no caso Marbury v. Madison (Estados Unidos, 1803), um ato contrário à Constituição é nulo e írrito (null and void) e não produz quaisquer efeitos, razão pela qual a decisão que declara a inconstitucionalidade no caso concreto deve operar de forma retroativa à elaboração do ato inconstitucional (efeitos ex tunc). Thomas Cooley $(1868$, p. 3) acrescentava que a "lei inconstitucional", para ele uma expressão enganosa, não era sequer uma lei ("in fact no law at all"), devendo-se considerá-la como se nunca tivesse existido.

Seguindo essa linha de raciocínio, uma lei contrária à Constituição teria sua execução automaticamente suspensa com a declaração de inconstitucionalidade, e qualquer medida posterior à decisão judicial, como a atuação do Senado Federal, mostra-se completamente desnecessária. Assim, Lúcio Bittencourt (1968, p. 145-146) considerava a 
expressão "suspensão da execução de lei inconstitucional" uma impropriedade técnica do legislador, uma vez que não restaria outra função ao mecanismo que não fosse dar maior publicidade à decisão do STF.

Gilmar Ferreira Mendes (2008, p. 274) notabilizou-se por defender os postulados de Bittencourt em tempos mais recentes. Acrescentou, ainda, que a partir de 1988 a competência do Senado Federal perdeu grande parte de seu significado com a predominância do controle abstrato no sistema brasileiro e com o reconhecimento de "efeitos transcendentes" às decisões do STF tomadas em controle difuso. Seria possível, então, falar-se em "uma autêntica mutação constitucional em razão da completa reformulação do sistema jurídico e, por conseguinte, da nova compreensão que se conferiu à regra do art. 52, inc. $X$, da Constituição de 1988". Para o jurista mato-grossense, "poder-se-ia cogitar aqui de uma autêntica reforma da Constituição sem expressa modificação do texto" (grifo no original).

Em sua atuação como Ministro do Supremo Tribunal Federal, Mendes protagonizou discussão emblemática sobre o tema quando do julgamento da Reclamação 4.335/AC, de sua relatoria ${ }^{3}$. No referido processo, a Defensoria Pública do Estado do Acre ajuizou Reclamação em face de decisão do Juiz da Vara de Execuções Penais de Rio Branco/ $A C$, que indeferiu o pedido de progressão de pena a dez detentos, todos eles condenados pela prática de crimes hediondos. A decisão atacada teria descumprido julgado do Supremo Tribunal Federal, que em

\footnotetext{
3 A tese do Ministro Gilmar Mendes (relator, 01/02/2007), no entan to, não prosperou na decisão final da corte. Após os votos dos Minis tros Eros Grau (voto-vista), Sepúlveda Pertence e Joaquim Barbosa (19/04/2007), o Ministro Ricardo Lewandowski pediu vista dos autos proferiu seu voto anos depois, apenas em 16/05/2013. Nesse espaço de tempo, foi editada Súmula Vinculante veiculando o entendimento do Habeas Corpus 82.959/SP, fazendo com que a discussão original perdesse objeto e a Reclamação fosse julgada procedente (Brasil, 2014).
}

sede do Habeas Corpus 82.959/SP, de relatoria do Ministro Marco Aurélio, afastara a vedação de progressão de regime prevista na Lei 8.072/90 (Lei de Crimes Hediondos), declarando a inconstitucionalidade do art. 2. ${ }^{\circ}, \S 2 .^{\circ}$, daquele diploma legal. O Ministro Gilmar Mendes votou pela procedência da Reclamação, concedendo a progressão de regime sob o argumento que as decisões do STF, inclusive em controle difuso, possuem eficácia vinculante, operando com efeitos erga omnes sem a necessidade de ato do Senado Federal que suspenda a execução da norma declarada inconstitucional. A Reclamação, portanto, seria um meio processual adequado para se obter tutela dessa espécie.

A tese defendida por Lúcio Bittencourt e Gilmar Mendes é duramente criticada por grande parte da doutrina. Lenio Streck (2014, p. 551) assevera que a exclusão da competência do Senado Federal "ou conferir-Ihe apenas um caráter de tornar público o entendimento do STF - significa reduzir as atribuições do Senado Federal à de uma secretaria de divulgação intralegislativa das decisões do Supremo". Nesse sentido, já sustentava Paulo Brossard (1976, p. 62):

\begin{abstract}
Atribuir ao Senado papel mecânico, fazê - lo autômato, transformá-lo em carimbo, meirinho, cartório ou porteiro de auditórios, não significa apenas atribuir-lhe uma função absolutamente subalterna, mas, e especialmente, sem qualquer significação e utilidade, tarefa que poderia ser desempenhada, com proficiência e vantagem, por qualquer funcionário da secretaria do Supremo Tribunal.
\end{abstract}

Evidentemente, não foi para essa função de amanuense que a Constituição de 34 reservou essa competência ao Senado, em caráter privativo.

O "esvaziamento" da função do Senado se 
mostra, de fato, bastante problemático. É preciso ressaltar que a divulgação das decisões do Supremo Tribunal Federal, inclusive as que tratam de controle incidental de constitucionalidade, já é levada a cabo pelo Diário de Justiça. Conforme lembrava Oswaldo Aranha Bandeira de Mello (1980, p. 205), a publicidade das decisões da Excelsa Corte "resulta da divulgação do resultado do feito, da própria decisão judicial, inserta em órgão oficial". Considerar a atribuição senatorial mera repetição desse labor deixa -a sem nenhuma relevância e certamente não foi esse o objetivo do constituinte.

Mesmo a "autêntica mutação constitucional", defendida por Gilmar Mendes, não é sustentável. Flávio Quinaud Pedrón (2015, p. 232) observa que a mutação constitucional é um fenômeno cuja ocorrência encontra determinados limites, dentre os quais a letra expressa da própria Constituição, cuja desobediência acaba por torná-la uma "mutação inconstitucional". Para Nelson Nery Júnior (2010, p. 199), a mutação constitucional é um processo de interpretação natural da Constituição que não pode ser construído de maneira forçada: "não se pode fazer tábua rasa do texto do art. 52, inc. X, da CF, que ainda se encontra em vigor e só pode ser desconsiderado por expressa mudança formal e material da Constituição".

Nesse mesmo sentido, Carlos Victor Nascimento dos Santos (2014, p. 601) concluiu, após análise empírica, que não houve modificação no comportamento do STF ou do Senado, mas, sim, "uma mudança de interpretação do texto constitucional em razão de elementos subjetivos do intérprete [referindo-se ao voto do Ministro Gilmar Mendes]. Assim, não há que se falar em mutação constitucional do disposto no art. 52, inc. $X$, da Constituição" (grifo no original).
Suplantada a primeira tese sobre o ato do Senado, uma segunda corrente doutrinária defende que cabe àquela casa legislativa avaliar os requisitos formais da decisão judicial, como por exemplo o respeito ao quórum mínimo de Ministros para julgamento em Plenário. Celso Ribeiro Bastos (1979, p. 85) afirmava não caber ao Senado a deliberação acerca de questões interna corporis do Supremo Tribunal Federal. CabeIhe, sim, examinar os requisitos constitucionais para a suspensão da norma e "nessas condições, em exercendo função própria do Legislativo, não se pode furtar à suspensão de lei declarada inconstitucional pelo STF". A função do Senado, portanto, seria fiscalizar a regularidade do julgado e, em seguida, executar o comando previsto na Constituição: suspender a execução do dispositivo eivado de inconstitucionalidade.

A redução do papel do Senado a "fiscal" da Constituição em relação à decisão judicial é igualmente problemática e também encontra bastante crítica na doutrina. Para Paulo Napoleão Nogueira da Silva (1992, p. 78), admitir-se a verificação dos requisitos formais da decisão do STF como único atributo do Senado Federal na competência do art. 52, inc. $X$, da Constituição foge à razoabilidade na interpretação "fático-jurídica" do dispositivo. Parece expressar a busca de uma secundaríssima justificação para a cláusula constitucional "por aqueles que, aferrados a uma noção dogmática do controle judicial exclusivo, precisam recusar conhecimento ao significado óbvio dessa cláusula e ao mesmo tempo justificar a sua existência".

De acordo com Paulo Brossard (1976, p. 57), "o Senado não é fiscal da Corte Suprema, nem tem por ofício cuidar da observância das regras de julgamento. Às partes, não ao Senado, é reservada essa vigilância". 
Por essa razão uma terceira corrente compreende o ato do Senado que suspende a execução de lei inconstitucional como um ato meramente político. Dessa forma, os senadores poderiam examinar a decisão de inconstitucionalidade "não apenas sob os aspectos formais, mas, também, quanto aos substanciais" (Ferraz, 2014, p. 1066). Já em 1966, quando do julgamento do Mandado de Segurança 16.512/DF, o Ministro Victor Nunes Leal asseverou que "o Senado terá seu próprio critério de conveniência e oportunidade para praticar o ato de suspensão" (Brasil, 1966).

A maior parte da doutrina acompanha esse acertado posicionamento, cuja análise apropriada exige o enfrentamento de outras importantes questões: primeiro, se há prazo legal para que o Senado aprecie a decisão comunicada pelo STF; segundo, se a competência do Senado, na matéria, é vinculada ou não ao mérito e à extensão da decisão de inconstitucionalidade; e terceiro, se uma vez editada a Resolução do Senado Federal (RSF), pode ela ser revogada ou não por outro ato do próprio Senado.

\subsection{Ausência de prazo para decisão}

Os termos "vinculado" e "discricionário" apresentam precisamente dois sentidos diversos ao caracterizar a competência privativa do Senado. De um lado, uma atuação vinculada pode significar um poder-dever, uma obrigação constitucional de atuação da casa legislativa a respeito da decisão que Ihe é remetida, não se admitindo, aqui, uma "não atuação". De outro lado, uma atuação vinculada pode fazer referência, também, ao limite do juízo do Senado em relação à extensão da declaração de inconstitucionalidade inserta em decisão do STF, ou seja, nesse caso, a suspensão pelo Senado estaria adstrita ao que foi decidido pelo órgão judiciário e os senadores não teriam o condão de modificar o sentido ou a extensão da declaração de inconstitucionalidade.

Por seu turno, o termo discricionário pode, a uma, significar ausência de obrigação do Senado em suspender a execução da norma inconstitucional, ou seja, os senadores podem decidir por suspendê-la ou não; e, a duas, referir-se ao limite do juízo senatorial, de modo que uma atuação discricionária permitiria ao Senado tomar uma decisão sem estar adstrito ao conteúdo da decisão judicial, podendo-se suspender ou não, parcial ou integralmente, a lei ou a parte da lei eivada de inconstitucionalidade.

O art. 52 da Constituição estabelece as competências privativas do Senado Federal. Para José Afonso da Silva (2002, p. 89), trata-se de norma de eficácia plena, o que implica, por um lado, a proibição de outras entidades ou órgãos exercerem aquelas atribuições e, por outro lado, a imposição ao titular da competência de realizarem determinada conduta na forma prevista, se ocorrerem certos pressupostos.

Lúcio Bittencourt (1968, p. 145) entendia o ato do Senado não como optativo, mas que "deve ser baixado sempre que se verificar a hipótese prevista na Constituição: decisão definitiva do STF". Nesse mesmo sentido, de acordo com o Ministro Pedro Chaves, o ato do Senado é executório, secundário, complementar, "consequente e subsequente àquele ato judiciário praticado pelo Supremo Tribunal Federal", uma vez que não poderia ser praticado se não preexistisse a decisão judicial (Brasil, 1966). Tratar-se-ia de competência vinculada no primeiro sentido do termo, não cabendo outra escolha à casa 
legislativa a não ser proceder com a suspensão da norma declarada inconstitucional.

Parte significativa da doutrina discorda desse entendimento. Paulo Napoleão Nogueira da Silva (1992, p. 74-75) pondera que a prática do ato senatorial não pode ser obrigatória justamente por se tratar de competência privativa, cujo exercício ocorre sem a interferência ou participação de outro órgão. A decisão do Supremo, aqui, é somente "uma espécie de requisito para o exercício da competência constitucional atribuída privativa e livremente ao Senado". Dessa forma, a norma do art. 52 tem eficácia plena, mas não vinculativa, "tanto assim que nenhuma sanção ou consequência positiva de qualquer natureza se conhece para o caso de tal ato deixar de ser praticado" (grifos no original).

Se a atividade do Senado, nessa matéria, fosse considerada obrigatória, dever-se-ia admitir procedimento judicial ou qualquer outra medida compulsiva para se exigir o cumprimento desse poder-dever. Já ponderava Oswaldo Aranha Bandeira de Mello (1980, p. 208) que o Supremo Tribunal Federal "nada solicita ao Senado; apenas dá a ele o conhecimento de sua decisão definitiva, para que exerça a faculdade que a Constituição Ihe atribui" (grifo no original). Dessa forma, não parece haver qualquer inconstitucionalidade na decisão do Senado em não suspender a execução da lei inconstitucional ou mesmo em não apreciar a decisão judicial que Ihe foi remetida. Conforme aponta Sérgio Rezende de Barros (2005, p. 146), o exercício dessa competência "não implica a aceitação da lei inconstitucional, não significa rejeitar a decisão do Supremo. Apenas constitui uma limitação política do âmbito e do modo de aplicação da inconstitucionalidade".
O caráter discricionário, no primeiro sentido do termo, é bem verdade uma consequência lógica da natureza política do ato do Senado. Os senadores avaliam a conveniência e a oportunidade de suspender ou não a execução da norma inconstitucional. Trata-se, pois, de uma competência genérica e não um dever determinado de agir, uma vez que não há qualquer sanção ou meio judicial que possibilite a exigência do cumprimento de uma "obrigação" constitucional.

Como expõe Clèmerson Merlin Clève (2000, p. 120), não há prazo para a deliberação do Senado Federal nessa matéria: "não especificando, a Constituição, prazo para a sua deliberação e, ademais, inexistindo sanção contra sua omissão, não é demais imaginar a possibilidade de o Senado manter-se inerte por anos a fio". No mesmo sentido, Gilmar Ferreira Mendes (2012, p. 1197) ressalta que "a inércia do Senado não afeta a relação entre os Poderes, não se podendo vislumbrar qualquer violação constitucional na eventual recusa à pretendida extensão de efeitos", do que conclui, de forma contrária à opinião exposta em artigos e no tribunal: "se pretendesse outorgar efeito genérico à decisão do Supremo Tribunal, não precisaria o constituinte valer-se dessa fórmula complexa".

\subsection{Possibilidade de recusa parcial ou in- tegral da suspensão da execução da lei}

A segunda acepção dos termos vinculado e discricionário diz respeito ao limite de atuação do Senado em relação ao conteúdo e à extensão da decisão de inconstitucionalidade. Clèmerson Merlin Clève (2000, p. 121) entende que "não está o Senado impedido de suspender a execução de parte apenas de uma lei declarada, por inteiro, inconstitucional pelo Supremo Tribunal Federal", seguin- 
do a orientação de Michel Temer (2004, p. 48), para quem as expressões "no todo" ou "em parte" são empregadas no art. 52, inc. X, com o mesmo sentido de outros dispositivos constitucionais e.g. art. $66, \S 1 .^{04}$, que trata da possibilidade de veto pelo Presidente da República. A dimensão desse veto é discricionária ao Chefe do Poder Executivo. $O$ emprego dos termos, portanto, teria semeIhante sentido no tocante à competência privativa do Senado e assim a Alta Casa do Congresso Nacional não teria a obrigação de suspender a execução da lei na mesma extensão da declaração efetivada pelo STF, ou seja, "se o STF declarar a inconstitucionalidade de lei, por inteiro, faculta-se ao Senado a possibilidade de suspendê-la [apenas] em parte".

Eduardo Talamini (2014, p. 698) acrescenta, ainda, que umas das consequências da discricionariedade do Senado Federal nessa matéria seria a possibilidade de modular os efeitos da suspensão da execução da norma inconstitucional:

Ao prever a possibilidade de o Senado
"suspender a execução, no todo ou em
parte", da "lei" declarada inconstitucio-
nal, a Constituição não está pretendendo
indicar que, se a declaração de incons-
titucionalidade for parcial, apenas essa
parte poderá ser "suspensa", e não o res-
to, tido por constitucional. Tal previsão
seria supérflua: o Senado jamais poderia
"suspender" a parte do ato normativo
que não é inconstitucional. Portanto, o
significado da ressalva é necessariamen-
te outro: autorizar o Senado a "suspen-
der" apenas uma parte da norma que
o Supremo considerou inconstitucional.
Consequentemente, o Senado pode mo-
dular a eficácia da retirada da norma do
ordenamento. Se lhe é dado até recusar
a retirada da norma, nada impede que

$\overline{4 \text { Art. 66. [...] \& } 7^{\circ}-\text { Se }}$ o Presidente da República considerar o projeto, no todo ou em parte, inconstitucional ou contrário ao interesse público, vetá-lo-á total ou parcialmente, no prazo de quinze dias úteis, contados da data do recebimento, e comunicará, dentro de quarenta e oito horas, ao Presidente do Senado Federal os motivos do veto (BRASIL, 1988, grifo nosso) a retire com eficácia ex nunc ou fixando algum outro termo que não o do surgimento da inconstitucionalidade. (grifos no original)

José Afonso da Silva (2014, p. 421) tem entendimento diverso, defendendo que o Senado somente poderá suspender por inteiro a lei que foi por inteiro declarada inconstitucional, não podendo fazê-lo apenas em parte, pois "quando o texto fala em suspender 'em parte', significa que também só dita parte foi declarada inconstitucional". Mais adiante, completa: "o ato de suspensão emitido pelo Senado tem que ser conforme o julgado. Não tem ele poder para modificar a decisão do STF".

Embora se discuta amplamente o alcance do juízo do Senado Federal, a maior parte da doutrina parece se alinhar à posição de José Afonso da Silva. Oswaldo Aranha Bandeira de Mello (1980, p. 209-210), por exemplo, ressaltava que o Senado não poderia funcionar como "revisor" da decisão do STF. As funções dos dois órgãos são claramente distintas: a do Supremo Tribunal Federal é declarar o ato inconstitucional na espécie e a do Senado é atribuir efeitos erga omnes à decisão quando entender oportuno e conveniente. A Alta Casa do Congresso pode, portanto, expandir ou não os efeitos da declaração de inconstitucionalidade, por suas próprias razões, e apreciar aspectos formais ou substanciais, sem imiscuir-se, contudo, no conteúdo da decisão, dada a impossibilidade de se modificar o que foi decidido pela corte.

Anna Cândida da Cunha Ferraz (2014, p. 1066) contra-argumenta de forma bastante acertada, afirmando que, embora o Senado Federal participe do sistema de fiscalização concreta de constitucionalidade, o ato de 
suspensão não traduz exercício de função jurisdicional. Trata-se de ato político-jurídico ou político-normativo, "quase legislativo", mas limitado, sem poder adentrar ao mérito da decisão e, assim, "não tem opção de suspender a execução de parte da lei, quando toda ela foi julgada inconstitucional, nem pode suspender toda a lei, quando apenas parte dela foi declarada inconstitucional pelo STF". Dessa forma, o Senado não pode ampliar ou restringir o conteúdo da decisão judicial encaminhada pelo STF.

A questão em análise é mais delicada do que aparenta. Uma atuação do Senado que extrapole o que foi estritamente determinado pela decisão do STF pode causar prejuízos de grandes proporções àqueles atingidos pela norma atacada. Há julgado relativamente recente do Supremo Tribunal Federal (Brasil, 2007) que corrobora a preocupação aqui levantada.

O Senado Federal, por meio da Resolução 7/2007, suspendeu a execução de quatro leis do Estado de São Paulo declaradas incidentalmente inconstitucionais em sede de três Recursos Extraordinários. No julgamento do primeiro deles, o RE 183.906/SP, declarou-se, incidenter tantum, a inconstitucionalidade parcial de lei paulista que previa destinação obrigatória da renda obtida por meio de majoração da alíquota de ICMS a determinado programa habitacional, o que é vedado pela Constituição Federal. Posteriormente, o julgamento dos RREE 188.443/SP e 213.739/SP, para além do vício já reconhecido no RE 183.906/ $\mathrm{SP}$, declarou incidentalmente inconstitucionais outras três leis estaduais que replicavam e prorrogavam a aplicação vinculada da majoração anteriormente prevista.

Ocorre que, por equívoco, o ofício endereçado ao Senado fez referência às últimas três leis em sua integralidade e não apenas aos trechos específicos efetivamente declarados inconstitucionais. Inadvertidamente, o Senado chancelou o descuido e a resolução acabou por ultrapassar o que fora, de fato, decidido pelo STF, suspendendo a eficácia das três leis por inteiro, inclusive as partes que não tinham sido declaradas inconstitucionais. A suspensão indevida acarretaria uma redução da ordem de $\mathrm{R} \$ 1,3$ bilhão na arrecadação fiscal do Estado de São Paulo, o que fez com que o então governador paulista, José Serra, propusesse uma ação direta de inconstitucionalidade contra a RSF 7/2007, atacando-a exatamente no trecho que extrapolou o disposto nos acórdãos do STF que a ela deu origem. A Ministra Ellen Gracie, Presidente da Corte à época, deferiu pedido de medida cautelar (ADI-MC 3.929/ DF), declarando parcialmente inconstitucional a Resolução do Senado, suprimindo a exata parte que tinha suspendido a execução de lei plenamente constitucional.

Ressalte-se que, no caso apresentado, por mais que tenha havido erro de comunicação no ofício encaminhado pelo STF, o Senado acabou por ultrapassar a exata extensão da inconstitucionalidade que havia sido declarada no acórdão, suspendendo a execução da parte da norma que remanescia em conformidade com a Constituição. A consequência desse tipo de atuação é evidentemente negativa e, inclusive, inconstitucional, razão pela qual foi combatida na ação direta de inconstitucionalidade há pouco referida. Já a hipótese contrária, ou seja, a suspensão de parte da lei que foi por inteiro declarada inconstitucional, mostra-se plenamente possível. Lembre-se, porém, que o Senado é um órgão político e essa atividade exige complexa interpretação jurídica. O mesmo vale para a modulação de efeitos, 
tarefa cuja realização cabe, em princípio, ao Poder Judiciário quando aprecia questão de constitucionalidade na espécie ou em tese.

\subsection{Impossibilidade de revogação da Re- solução do Senado}

Para além dos limites da atuação do Senado em relação à decisão do Supremo Tribunal Federal, é preciso analisar, também, a possibilidade de revogação da resolução suspensiva pelo próprio órgão que a editou, ou seja, o Senado Federal.

Para José Celso de Mello Filho (1986, p. 183), na esteira da maior parte da doutrina, o Senado "exaure sua competência constitucional no momento em que promulga e edita a resolução suspensiva. Não pode, ao depois, a pretexto de melhor interpretar a decisão judicial proferida pelo STF, modificar-lhe o sentido ou restringir-lhe os efeitos". Esse é o entendimento da própria corte suprema que, em 1966, ao julgar o já citado MS 16.512/ DF, anulou resolução senatorial que revogava resolução suspensiva anterior. Em seu voto, o Ministro Gonçalves de Oliveira destacou que "o Senado se manifestando, dá-se a exaustão de sua competência, não pode voltar atrás, e, fazendo-o, comete ato anulável pelo STF" (Brasil, 1966). Neste ponto, é a competência do Senado, exclusivamente, que se exaure: é a casa legislativa que não poderá mais modificar a resolução que produziu.

Duas observações ainda merecem ser feitas. Primeiro, nada obsta que o Supremo Tribunal Federal, órgão judiciário que é, ataque a resolução suspensiva por vício de inconstitucionalidade, como no caso da referida ADI-MC 3.929/DF, quando a resolução senatorial ultrapassou os limites da decla- ração de inconstitucionalidade que the deu origem. Mostra-se evidente, portanto, que a resolução suspensiva inconstitucional, assim como qualquer outro ato normativo eivado de inconstitucionalidade, pode e deve ser objeto de controle de constitucionalidade, seja em tese ou in casu.

Segunda observação: o Supremo pode modificar seu entendimento em relação ao julgado já remetido ao Senado e ainda não apreciado por aquela casa legislativa. Paulo Brossard (1976, p. 62-63) já alertava sobre as consequências negativas que a atuação do Senado com base em apenas um único julgado pode acarretar, afinal, se o Supremo revisa suas próprias súmulas, que compendiam jurisprudência consolidada e tranquila, "agirá o Senado com sabedoria se suspender a execução de lei com base apenas em um julgado, ainda que unânime, do Supremo Tribunal?". Para Brossard, as características e singularidades do caso concreto podem reclamar soluções distintas "e esses matizes factuais contribuem para revelar o que até então permanecera irrevelado no ventre da lei".

Nesse caso, assevera Gilmar Ferreira Mendes (2012, p. 1197) que a suspensão superveniente não deverá produzir consequência juridicamente relevante para o julgado que veicula entendimento diverso, uma vez que as decisões judiciais são protegidas pela força da coisa julgada. O elemento temporal afeto à atuação do Senado foi estabelecido pelo constituinte justamente para as ocasiões em que possa haver mudança na jurisprudência. Uma vez que o Senado decida por suspender a execução do dispositivo então declarado inconstitucional, o fará por definitivo, e por essa razão a Constituição permite ao Senado aguardar e observar as mudanças da jurisprudência, atuando ape- 
nas no momento em que entender oportuno e conveniente. Os efeitos da resolução suspensiva não atingirão o caso que veiculou entendimento diverso nesse interstício temporal.

\subsection{Efeitos temporais da Resolução do Senado}

O processo legislativo brasileiro compreende a elaboração de resoluções (CF-88, art. 59 , inc. VII) e de outras espécies normativas. Não tendo o constituinte definido expressamente o que é e quais atos devem ser veiculados por resolução ${ }^{5}$, coube à doutrina estabelecer sua definição como como ato normativo primário editado pelo Congresso Nacional, em sessão conjunta ou de cada uma de suas casas em particular, que visa formalizar deliberação tomada sobre matéria de sua competência privativa, regulamentando questão interna corporis de caráter político ou administrativo (Silva, 1992 , p. 86; 2014, p. 443). O procedimento de elaboração de resoluções é definido em regimento interno e não encontra revisão, sanção ou promulgação em órgão diverso daquele que a editou.

Não se discute que o veículo mais adequado para o exercício da competência privativa do Senado em suspender a execução de lei declarada inconstitucional é a Resolução do Senado Federal (RSF). É preciso verificar, porém, quais seus efeitos temporais, se retroativos (ex tunc) ou prospectivos (ex nunc).

Trata-se de matéria bastante controvertida. A teoria clássica sobre o ato inconstitucional,

5 A Constituição Federal de 1988 menciona "resolução", para além do art. 59, em dois outros artigos: o art. 68, que trata sobre leis delegadas, dispõe em seu § $2 .^{\circ}$ que a "delegação ao Presidente da República terá a forma de resolução do Congresso Nacional"; e o art. 155 , que trata da instituição de impostos sobre "operações relativas à circulação de mercadorias e sobre prestações de transporte interestadual e intermunicipal e de comunicação", menciona, em seu $\S 2$. inc. IV e V, o uso da resolução pelo Senado Federal para fixação de alíquotas. embora considere como se tal ato nunca tivesse existido, reconhece a importância de alguns efeitos por ele produzidos que não podem ser simplesmente ignorados. Conforme observou o Chief Justice da Suprema Corte dos Estados Unidos, Charles Hughes, no julgamento do caso Chicot County Drainage Dist. v. Baxter State Bank (Estados Unidos, 1940), nem sempre o passado pode ser "apagado" por uma declaração judicial ("the past cannot always be erased by a new judicial declaration").

No sistema brasileiro, a declaração abstrata de inconstitucionalidade é dotada de eficácia contra todos e opera, em princípio, com efeitos retroativos, podendo o Supremo Tribunal Federal lançar mão da modulação dos efeitos da decisão quando razões de segurança jurídica ou de excepcional interesse social a justifiquem, conforme estabelece a Lei n. ${ }^{\circ}$ 9.868, que dispõe sobre o processo e julgamento da ação direta de inconstitucionalidade e da ação declaratória de constitucionalidade.

A declaração incidental de inconstitucionalidade também opera com efeitos ex tunc como princípio geral. Entretanto, conforme observa Eduardo Talamini (2014, p. 683684), "é o controle incidental, que examina a compatibilidade da lei com a Constituição à luz do caso concreto, o campo por excelência para o emprego da técnica da preservação dos efeitos". Acrescenta, ainda: "haverá situações em que só no caso concreto será viável a ponderação de valores, a fim de se verificar a necessidade de preservação de determinados efeitos da norma inconstitucional".

De um lado, é possível compreender que o ato do Senado tenha como função atribuir eficácia erga omnes à declaração de inconstitucionalidade tomada no caso concreto. 
Dessa forma, uma declaração com efeitos ex tunc ou ex nunc, mas originalmente restrita às partes litigantes, seria "ampliada" e passaria a operar contra todos. Para Gilmar Mendes (2008, p. 260), parecia evidente aos constituintes que a suspensão da execução da lei "importava na extensão dos efeitos do aresto declaratório da inconstitucionalidade [...]. Atribuía-se, pois, ao ato do Senado caráter ampliativo e não apenas paralisante ou derrogatório do diploma viciado" (grifos no original) ${ }^{6}$.

De outro lado, é possível considerar a suspensão da execução como se fosse uma "revogação" da lei declarada inconstitucional. Oswaldo Aranha Bandeira de Mello (1980, p. 211) afirmava que a Resolução do Senado Federal "apenas cassa a lei, que deixa de obrigar, e, assim, perde a sua executoriedade porque, dessa data em diante, a revoga simplesmente" (grifo nosso). A partir desse raciocínio, a resolução suspensiva teria caráter constitutivo e só a partir de sua edição é que a lei perderia eficácia (Ferrari, 2004, p. 205).

Anna Cândida da Cunha Ferraz (2014, p. 1066) pondera que o Senado não revoga propriamente a lei, mas expede resolução cujos efeitos são semelhantes aos da revogação, ou seja, ex nunc, "permanecendo intocáveis os efeitos já produzidos pela norma enquanto ainda não considerada inconstitucional pelo STF, não prejudicando as situações jurídicas já constituídas".

O dilema é considerável: à necessidade de se limitar ao disposto na decisão judicial, soma-se o dever do Senado Federal de preservar os atos emanados da norma inconstitucional antes da suspensão de sua execução.

6 Clèmerson Merlin Clève (2000, p. 122-124) e Luís Roberto Barroso (2012, p. 157) compartilham de semelhante entendimento.
Nesse particular, outros dois aspectos merecem destaque. Em primeiro lugar, conforme exposto anteriormente, o vocábulo "suspensão" empregado no texto constitucional designa uma medida de caráter definitivo e irrevogável, e não provisório como a simples interpretação gramatical pode dar a entender. Para Fernando Dias Menezes de Almeida (2007, p. 18), a edição da resolução invalida e retira do ordenamento a norma "suspensa", e é coerente que nem o Supremo Tribunal Federal (e nem nenhum outro órgão) possa voltar a aplicá-la.

Em segundo lugar, a atuação do Senado é discricionária e não encontra balizas temporais. Ocorre, portanto, necessariamente em momento posterior à declaração de inconstitucionalidade pelo STF e suspende ou não a execução da lei de acordo com critérios eminentemente políticos, de conveniência e oportunidade, percebidos somente por aquela casa legislativa. São elementos externos, alheios à decisão judicial, que fundamentarão a medida.

Observam-se, portanto, três situações distintas: primeiro, a declaração abstrata de inconstitucionalidade com efeitos em princípio ex tunc e eficácia erga omnes; segundo, a declaração incidental de constitucionalidade com efeitos em princípio ex tunc e eficácia inter partes; e terceiro, a suspensão pelo Senado da execução de lei declarada inconstitucional, com efeitos em princípio ex nunc e eficácia contra todos, exceto nos casos de suspensão da execução de leis penais, que naturalmente operam de forma retroativa em benefício do réu, ou quando a Resolução do Senado estabelece a retroação de forma expressa?.

7 É o caso da RSF 3/2008, que estabelece estar "suspensa a execução, com efeito ex tunc, do parágrafo único do art. 11 da Lei n 9.639, de 25 de maio de 1998 [...]" (Brasil, 2008). 
O elemento temporal é decisivo para essa conclusão. Se o constituinte legou ao Senado a competência para ampliar os efeitos da decisão individual necessariamente depois de lavrado o acórdão, é porque se trata de regime evidentemente diverso ao da fiscalização efetuada pelo Judiciário. Se se tratasse de extensão pura e simples da decisão, dotando-a de efeitos retroativos e eficácia contra todos, como ocorre no controle abstrato, a previsão de lapso temporal "discricionário" entre a decisão judicial e a decisão senatorial pela suspensão da execução do dispositivo não faria diferença alguma. Ao contrário, seria um obstáculo a mais para atingir os objetivos do dispositivo. Certamente não foi essa a intenção do constituinte, de acordo com Paulo Napoleão Nogueira da Silva (1992, p. 110-111):

Não teria sentido, e nem o permitiria a lógica do sistema, que qualquer dessas decisões [em controle abstrato, difuso ou a suspensão pelo Senado] fosse integrante, uma espécie de adendo de qualquer das demais; ou, ainda, que qualquer das duas primeiras determinasse automaticamente a existência ou prolação da terceira, sem que qualquer outro elemento ou requisito de natureza cognitiva e decisória se fizesse presente para autorizá-la [...]. No controle incidental, o Supremo forma livremente o seu convencimento para declarar ou não a inconstitucionalidade, nada o obrigando a fazê-lo ou a deixar de fazê-lo, senão motivos do próprio convencimento; e nesse mister se exaure a sua participação no procedimento. $O$ Senado, na etapa em que lhe compete atuar, forma livremente o seu convencimento político sobre a conveniência e oportunidade de estender ou não, a todos e para o futuro, aquilo que o Supremo declarou com eficácia restrita às partes [...]. Declarar a inconstitucionalidade entre partes e, como regra fazê-lo com eficácia retroativa, é função completamente diversa daquela de estender a todos e para o futuro a eficácia e os efeitos dessa declaração.
Sobre essa questão, é necessário fazer referência ao Decreto n. 2.346/97 da Presidência da República (Brasil, 1997, grifos nossos), que dispõe:

\begin{abstract}
Art. 1. ${ }^{\circ}$ As decisões do Supremo Tribunal Federal que fixem, de forma inequívoca e definitiva, interpretação do texto constitucional deverão ser uniformemente observadas pela Administração Pública Federal direta e indireta, obedecidos aos procedimentos estabelecidos neste Decreto.
\end{abstract}

$\S 1 .^{\circ}$ Transitada em julgado decisão do Supremo Tribunal Federal que declare a inconstitucionalidade de lei ou ato normativo, em ação direta, a decisão, dotada de eficácia ex tunc, produzirá efeitos desde a entrada em vigor da norma declarada inconstitucional, salvo se o ato praticado com base na lei ou ato normativo inconstitucional não mais for suscetivel de revisão administrativa ou judicial.

\begin{abstract}
$\S 2 .^{\circ}$ O disposto no parágrafo anterior aplica-se, igualmente, à lei ou ao ato normativo que tenha sua inconstitucionalidade proferida, incidentalmente, pelo Supremo Tribunal Federal, após a suspensão de sua execução pelo Senado Federal.
\end{abstract}

Por mais que o $\S 2 .^{\circ}$ mencione a atuação do Senado, não há prejuízo da Administração Pública e do Poder Judiciário deixarem de aplicar a norma inconstitucional com efeitos retroativos (ex tunc), mesmo que a Resolução do Senado não os determine expressamente. Ocorre que, nesses casos, os eventuais efeitos retroativos terão exclusivamente como base a decisão do Supremo Tribunal Federal tomada em controle difuso, cujo valor será de precedente não vinculante. Afinal, lembrava Paulo Brossard (1976, p. 62), o Senado, em suspendendo a execução da lei inconstitucional, "realiza tarefa de política legislativa e de saneamento da ordem jurídica" e por essa razão seus efeitos operam, de forma automática, apenas de modo prospectivo (ex nunc). 


\subsection{Conclusões preliminares}

Feitas essas considerações de cunho teóri$\mathrm{co}$, as conclusões preliminares permitem a elaboração de respostas às perguntas elencadas no início deste capítulo.

Primeiro, o ato do Senado que suspende a execução de lei declarada inconstitucional é um ato veiculado por Resolução do Senado Federal cuja natureza é eminentemente política. Dessa forma, será baixado se e quando os senadores entenderem oportuno e conveniente. Não se trata de revogação da lei, tampouco de ato que "dá maior publicidade" à declaração de inconstitucionalidade. Trata-se de ato normativo sui generis que suspende a execução da norma legal com efeitos erga omnes.

Segundo, a atuação do Senado não é obrigatória. Não há prazo legal para que ela ocorra e não há sanção por eventual omissão do órgão legislativo, ou seja, não se mostra possível exigir judicialmente o exercício dessa competência privativa.

Terceiro, o Senado pode se recusar a suspender a execução da lei declarada inconstitucional, ou mesmo suspender apenas parte da lei que foi, por inteiro, declarada inconstitucional (podendo modular os efeitos dessa suspensão). Não se mostra possível, porém, a suspensão da execução, pelo Senado, da parte da lei que não foi declarada inconstitucional pelo Supremo Tribunal Federal.

Quarto, o termo "suspensão" não indica uma providência temporária, mas, ao contrário, uma providência definitiva. Uma vez suspensa a execução da norma, esta passa a não mais produzir efeitos, razão pela qual a Resolução do Senado que a suspendeu não pode ser revogada por outro ato do próprio Senado.
Quinto, por fim, a suspensão da execução de lei inconstitucional opera, automaticamente, com efeitos prospectivos (ex nunc), salvo em casos especiais, como os de suspensão da execução de leis penais em benefício do réu, naturalmente retroativos, ou quando a Resolução do Senado estabeleça a retroação de forma expressa. Admite-se a possibilidade, também, da Administração Pública e do Poder Judiciário deixarem de aplicar a lei retroativamente. Nesse caso, porém, esses órgãos tomarão como base apenas a decisão do Supremo Tribunal Federal que embasou a Resolução do Senado, e não a Resolução do Senado em si.

\section{PESQUISA EMPÍRICA}

Enquanto alguns aspectos da competência do Senado estudada neste trabalho permitem elucidação de cunho eminentemente teórico - sobretudo aqueles aspectos decorrentes de interpretação do texto constitucional - outros podem ser melhor esclarecidos a partir da análise do comportamento das instituições envolvidas.

Neste capítulo, pretende-se analisar o comportamento de Supremo Tribunal Federal e Senado na vigência da Constituição Federal de 1988. Os documentos levantados dizem respeito à comunicação entre ambos (para fins do art. 52, inc. $X$, da Constituição) no período que vai de outubro de 1988 a novembro de 2016.

\subsection{Apontamentos metodológicos}

Foram colhidas informações junto à Secretaria Judiciária do STF, que gentilmente forneceu mídia eletrônica contendo cópia integral de todos os Ofícios "PM-C" enviados ao 
Senado entre 1988 e $2014^{8}$, e à Secretaria de Informação Legislativa do Senado, que encaminhou uma planilha com informações detalhadas sobre os Ofícios "S" recebidos no mesmo período.

A tramitação individual das comunicações no Senado Federal pôde ser conferida no portal "Atividade Legislativa" e nos Relatórios Anuais da Presidência, todos eles disponíveis no sítio eletrônico da casa legislativa. Esses dados foram reunidos em uma base comum, o que permitiu a elaboração dos gráficos e tabelas apresentados neste artigo.

É preciso esclarecer que a pesquisa não efetuou o levantamento de todas as decisões do Supremo que, no período analisado, poderiam efetuar controle difuso de constitucionalidade e naturalmente ensejariam comunicação ao Senado. Esse levantamento, ideal para verificar se todas as declarações incidentais de inconstitucionalidade são efetivamente comunicadas ao Senado, seria, no entanto, demasiado robusto (compreenderia a análise de mais de 200.000 acórdãos, de acordo com informações do sítio eletrônico do Supremo9 ${ }^{9}$. Como se verá adiante, o levantamento documental que foi realizado permitiu analisar a questão a partir de outros elementos.

É válido registrar, também, que o Gabinete da Presidência do Supremo, então ocupada pelo Ministro Ricardo Lewandowski, respondeu ao contato do autor assegurando

\footnotetext{
8 A título de esclarecimento, os ofícios são numerados na origem como "PM-C" e renumerados como Ofício "S" pelo Serviço de Protocolo do Senado. A partir desta última referência, é possível acompanhar toda a tramitação da documentação na casa legislativa. Pôde-se constatar, no período pesquisado, que não houve perda de informação na remessa de ofícios, ou seja, todos os ofícios encaminhados pelo STF efetivamente foram recebidos pelo Senado. Por essa razão, a atualização de dados - referente ao período que vai de janeiro de 2015 a novembro de 2016 - tomou como base apenas a tramitação da comunicação a partir de sua recepção pelo Senado, sem prejuízo aos resultados da pesquisa.

9 O número total de processos protocolados, distribuídos e julgados pelo Supremo Tribunal Federal está disponível no sítio eletrônico da corte, a partir do comando <http://www.stf.jus.br/portal/cms/verTexto. asp?servico=estatistica\&pagina=pesquisaClasse>
}

(e dificilmente seria diferente) que é prática reiterada da corte cumprir rigorosamente os dispositivos de seu Regimento Interno, inclusive no que diz respeito à comunicação ao Senado das decisões que exercem controle difuso de constitucionalidade, obedecendo-se à seguinte sequência: julgamento - trânsito em julgado - comunicação assinada pelo Presidente do STF - envio ao Senado Federal.

O processamento das informações coletadas levou em conta diversas variáveis. Primeiro, foi verificado se todos os Ofícios "PM-C" encaminhados pelo Supremo foram efetivamente recebidos pelo Serviço de Protocolo do Senado e renumerados como Ofício " $S$ ". O resultado foi afirmativo, ou seja, não houve perda de informação na remessa de ofícios. Em seguida, foi possível classificar todas as declarações de inconstitucionalidade comunicadas ao Senado por "classe processual", isto é, pelo tipo de ação que as originou, e também por objeto, ou seja, pelo tipo de norma impugnada. Esse trabalho permitiu encontrar elementos para responder às seguintes questões:

1. Quais os tipos de ação que originaram as comunicações feitas entre Supremo Tribunal Federal e Senado de 1988 a 2016?

2. Qual a espécie normativa e a origem das normas cuja declaração de inconstitucionalidade foi comunicada ao Senado?

3. A frequência de Ofícios "PM-C" enviados ao Senado guarda relação com os tipos de ação que os embasaram, com alguma característica da norma impugnada ou, mesmo, com os mandatos dos Presidentes do Supremo Tribunal Federal?

Em um segundo momento, foi conferida a tramitação individual de todas as comuni- 
cações recebidas pelo Serviço de Protocolo do Senado. Os Ofícios "S" foram classificados pelo último estado de tramitação e pelo espaço de tempo compreendido desde o envio pelo Supremo Tribunal Federal até o último estado de tramitação. As informações coletadas possibilitaram esboçar respostas para as seguintes perguntas:

1. Há alguma relação entre o último de estado de tramitação e a origem ou tipo da norma impugnada?

2. Há alguma relação entre o tempo de tramitação da comunicação no Senado e o seu conteúdo (origem ou tipo da norma impugnada)?

Além das perguntas acima elencadas, a pesquisa empírica quantitativa pôde complementar a segunda conclusão preliminar obtida pela análise dogmática do art. 52, inc. X, da Constituição Federal - a de que a atuação do Senado não é obrigatória e não encontra prazo legal para sua ocorrência.

\subsection{Comunicações ao Senado e sua ori- gem e objeto}

Nas palavras de Luís Roberto Barroso (2012, p. 113), o controle difuso de constitucionalidade é a única via acessível ao cidadão comum para a tutela de seus direitos constitucionais, uma vez que a questão constitucional pode ser suscitada em processos de qualquer natureza - de conhecimento, de execução ou cautelar - em qualquer instância do Judiciário, inclusive o Supremo Tribunal Federal.

Dessa forma, presume-se que é possível o Supremo declarar incidentalmente a inconstitucionalidade de uma norma em quaisquer processos de sua competência, com exceção daqueles que exercem con- trole abstrato (ADI, ADC, ADO e ADPF). Conforme estabelece o art. 178 do regimento interno da corte, após o trânsito em julgado dos processos em que há controle difuso, a Secretaria Judiciária faz comunicação da decisão ao Senado - via Ofício "PM-C" assinado pelo Presidente do Supremo.

A tabela 1 classifica os Ofícios "PM-C" por classe processual de origem. Em 1989 e 1990, dois acórdãos de Ação Direta de Inconstitucionalidade (ADI) foram equivocadamente comunicados ao Senado - percebe-se que nos anos seguintes nenhuma decisão dessa natureza foi remetida à casa legislativa. Quanto às outras classes processuais, destacam-se Ação Originária (AO), Habeas Corpus (HC), Mandado de Segurança (MS) e Recurso Extraordinário (RE).

É possível perceber que não há grande variação no número de comunicações das decisões em Habeas Corpus e Mandado de Segurança ano a ano em todo o período pesquisado - de 1 a 3 comunicações. Já as decisões em Ação Originária, por sua vez, concentram-se no período que vai de 1995 a 2004 (34 comunicações), com apenas 1 comunicação fora desse período, em 2009.

Os Ofícios "PM-C" com origem em Recurso Extraordinário - classe processual que representa mais de $68 \%$ das comunicações no período pesquisado - não apresentam uma frequência regular ano a ano. De 2005 em diante, porém, é notável a diminuição da quantidade global de comunicações, certamente uma consequência da entrada em vigor da Emenda Constitucional 45/2004, que estabeleceu o requisito da repercussão geral.

Até 2004, foram 117 comunicações de RE, o que representa $66 \%$ do total de comunicações em igual período (177). De 2005 em diante, foram $49 \mathrm{RE}$ comunicados de um 
total de 64 de comunicações - 76,5\%, portanto. De acordo com informações do sítio eletrônico do próprio Supremo Tribunal Federal, as decisões em Recurso Extraordinário representaram $74,3 \%$ do total de processos julgados pela corte em igual período. Trata-se de um número muito próximo ao de comunicações de RE em relação ao todo (76,5\%), o que de certa forma pode levar a conclusão que a frequência de comunicações ao Senado não destoa da média de julgamentos de processos pela corte - descontando-se, claro, os julgamentos em processos de natureza objetiva.

TABELA 1 - OFÍCIOS “PM-C” POR CLASSE PROCESSUAL (1988-2016)

TABLE 1 - OFÍCIOS “PM-C” BY PROCEDURAL CATEGORY (1988-2016)

\begin{tabular}{|c|c|c|c|c|c|c|c|c|c|c|}
\hline \multirow{2}{*}{ Ano } & \multicolumn{9}{|c|}{ Classe processual } & \multirow{2}{*}{ Total } \\
\hline & \multirow[t]{2}{*}{$\mathrm{ACO}$} & \multirow[t]{2}{*}{$\mathrm{AO}$} & \multirow[t]{2}{*}{$\mathrm{Al}$} & \multirow[t]{2}{*}{$\mathrm{HC}$} & \multirow[t]{2}{*}{ Inq } & \multirow[t]{2}{*}{ MS } & \multirow[t]{2}{*}{$\mathrm{Rcl}$} & \multirow[t]{2}{*}{$\mathrm{RE}$} & \multirow[t]{2}{*}{ ADI } & \\
\hline 1988 & & & & & & & & & & 0 \\
\hline 1989 & 1 & & & & & & & & 1 & 2 \\
\hline 1990 & & & & & & & & 2 & 1 & 3 \\
\hline 1991 & & & & & & 1 & & & & 1 \\
\hline 1992 & & & & & & & & 3 & & 3 \\
\hline 1993 & & & & & & 3 & & 5 & & 8 \\
\hline 1994 & & & & & & & & 4 & & 4 \\
\hline 1995 & & 4 & & & & 1 & & 8 & & 13 \\
\hline 1996 & & 13 & & 1 & & 1 & & 3 & & 18 \\
\hline 1997 & & 6 & & 1 & & 1 & & 13 & & 21 \\
\hline 1998 & & 2 & & & & 1 & & 8 & & 11 \\
\hline 1999 & & 1 & & & & 1 & & 16 & & 18 \\
\hline 2000 & & 3 & & 1 & & 1 & & 8 & & 13 \\
\hline 2001 & & 2 & & 3 & & & & 7 & & 12 \\
\hline 2002 & 1 & 1 & & & & & & 18 & & 20 \\
\hline 2003 & 2 & 1 & & 1 & & & 1 & 6 & & 11 \\
\hline 2004 & & 1 & & & 1 & 1 & & 16 & & 19 \\
\hline 2005 & & & & & & & & 7 & & 7 \\
\hline 2006 & & & & 2 & & & & 5 & & 7 \\
\hline 2007 & & & 2 & & & & & 2 & & 4 \\
\hline 2008 & & & & & & & & 3 & & 3 \\
\hline 2009 & & 1 & & 1 & & 1 & & 6 & & 9 \\
\hline 2010 & & & & & & & & 2 & & 2 \\
\hline 2011 & & & & 1 & & 1 & & 3 & & 5 \\
\hline 2012 & & & & & & & & & & 0 \\
\hline 2013 & & & & & & & & 3 & & 3 \\
\hline 2014 & & & & 1 & & 2 & & 10 & & 13 \\
\hline 2015 & & & & 2 & & & & 6 & & 8 \\
\hline 2016 & & & & 1 & & & & 2 & & 3 \\
\hline Total & 4 & 35 & 2 & 15 & 1 & 15 & 1 & 166 & 2 & 241 \\
\hline
\end{tabular}

FONTE: Elaboração do autor. 
A tabela 2 classifica os Ofícios "PM-C" por objeto, ou seja, por norma impugnada. Percebe-se, em primeiro lugar, que se adotou uma interpretação extensiva do vocábulo "lei" inserto na redação do art. 52, inc. X, da Constituição Federal. Em outras palavras, comunicou-se ao Senado tanto as declarações de inconstitucionalidade de normas federais quanto de normas estaduais e municipais, e mesmo de leis ordinárias quanto atos infralegais (decretos, regulamentações, portarias etc.).

Conforme observa Anna Cândida da Cunha Ferraz (2014, p. 1066), levando-se em conta a finalidade do mecanismo, é de se entender que todo ato jurídico normativo sujeito à fiscalização do Supremo Tribunal Federal possa constituir objeto de Resolução do Senado que suspenda sua execução. Precípua é a afirmação de Oswaldo Aranha Bandeira de Mello (1980, p. 207) nessa matéria:

Como ao Supremo Tribunal Federal competia, em definitivo, em última instância, declarar a inconstitucionalidade não só de lei ou decreto federal, mas também de lei ou decreto estadual, municipal e territorial, a suspensão desses textos, em virtude daquelas decisões, em não tendo feito a Constituição qualquer restrição, haveria de compreender os declarados inconstitucionais de qualquer das entidades. Mesmo porque essa suspensão, conforme a sistemática adotada, constitui uma atividade acessória à declaração de inconstitucionalidade, complementar a ela.

É preciso ressaltar que um Ofício "PM-C" pode ter por objeto mais de uma lei ou parte de lei declarada inconstitucional pelo Supremo, razão pela qual o número total dispositivos impugnados (282) é maior que o de ofícios remetidos (241, conforme de- monstra a tabela 1).

Além disso, é possível inferir um certo equilíbrio entre a origem dos dispositivos impugnados. As normas de âmbito federal representaram 36,5\% das comunicações ao Senado, enquanto as de âmbito estadual e municipal representaram 39,7\% e 23,7\%, respectivamente.

\section{TABELA 2 - OFÍCIOS “PM-C" POR OBJETO (1988-2016) TABLE 2 - OFÍCIOS “PM-C" BY OBJECT (1988-2016)}

\begin{tabular}{|c|c|c|c|c|c|c|c|c|}
\hline \multirow{3}{*}{\begin{tabular}{|c|} 
Âmbito \\
Tipo \\
1988 \\
\end{tabular}} & \multicolumn{2}{|c|}{ Federal } & \multicolumn{3}{|c|}{ Estadual } & \multicolumn{3}{|c|}{ Municipal } \\
\hline & \multirow[t]{2}{*}{ 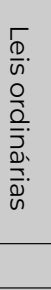 } & \multirow[t]{2}{*}{ 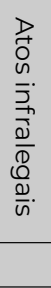 } & \multirow[t]{2}{*}{ 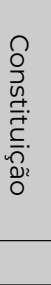 } & \multirow[t]{2}{*}{ 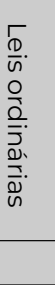 } & \multirow[t]{2}{*}{ 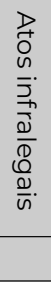 } & \multirow[t]{2}{*}{ 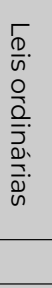 } & \multicolumn{2}{|l|}{ 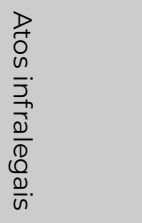 } \\
\hline & & & & & & & & 0 \\
\hline 1989 & 1 & 1 & & 0 & 0 & 0 & & 2 \\
\hline 1990 & 1 & 0 & & 1 & 0 & \multicolumn{2}{|l|}{1} & 3 \\
\hline 1991 & 1 & 0 & & 0 & 0 & 0 & & 1 \\
\hline 1992 & 2 & 0 & & 2 & 0 & 0 & & 4 \\
\hline 1993 & 6 & 1 & & 4 & 0 & 0 & & 11 \\
\hline 1994 & 2 & 0 & & 2 & 0 & 1 & & 5 \\
\hline 1995 & 8 & 0 & & 7 & 0 & 1 & & 16 \\
\hline 1996 & 2 & 0 & 1 & 25 & 0 & 0 & & 28 \\
\hline 1997 & 2 & 3 & & 8 & 1 & 7 & & 21 \\
\hline 1998 & 2 & 1 & & 3 & 0 & 5 & & 11 \\
\hline 1999 & 4 & 0 & & 7 & 1 & 10 & & 22 \\
\hline 2000 & 5 & 0 & & 3 & 0 & 5 & & 13 \\
\hline 2001 & 1 & 0 & 1 & 7 & 1 & 4 & & 14 \\
\hline 2002 & 3 & 0 & 2 & 3 & 0 & 13 & 1 & 22 \\
\hline 2003 & 2 & 0 & 4 & 5 & 1 & 0 & & 12 \\
\hline 2004 & 3 & 1 & 2 & 2 & 0 & 12 & & 20 \\
\hline 2005 & 1 & 0 & 5 & 2 & 2 & 1 & & 11 \\
\hline 2006 & 5 & 1 & & 1 & 1 & 0 & & 8 \\
\hline 2007 & 0 & 1 & & 1 & 1 & 0 & & 3 \\
\hline 2008 & 4 & 0 & & 1 & 0 & 0 & & 5 \\
\hline 2009 & 7 & 1 & & 1 & 1 & 0 & & 10 \\
\hline 2010 & 1 & 1 & & 0 & 0 & 0 & & 2 \\
\hline 2011 & 3 & 0 & & 1 & 0 & 1 & & 5 \\
\hline 2012 & 0 & 0 & & 0 & 0 & 1 & & 1 \\
\hline 2013 & 3 & 0 & & 0 & 0 & 0 & & 3 \\
\hline 2014 & 13 & 1 & & 0 & 0 & 1 & & 15 \\
\hline 2015 & 5 & 2 & 1 & 0 & 0 & 3 & & 11 \\
\hline \multirow[t]{2}{*}{2016} & 2 & 0 & & 0 & 1 & 0 & & 3 \\
\hline & 89 & 14 & 16 & 86 & 10 & 66 & 1 & 282 \\
\hline
\end{tabular}

FONTE: Elaboração do autor. 
A tabela 3, por fim, exibe a quantidade de Ofícios "PM-C" encaminhados ao Senado por cada Presidente do Supremo Tribunal Federal desde 1988 até 2016. Os mandatos dos presidentes da corte têm duração máxima de 2 (dois) anos, de acordo com o art. 12 do regimento interno daquela instituição. Em todo o período pesquisado, apenas os Ministros Aldir Passarinho, Maurício Corrêa e Ayres Britto exerceram por curto período de tempo a Presidência do Supremo, razão pela qual dois deles - Aldir Passarinho e Ayres Britto - não encaminharam um Ofício "PM-C" sequer durante seus mandatos.

É possível perceber, também, que não há uma regularidade no número de decisões de inconstitucionalidade comunicadas ao
Senado em cada mandato de Presidente do Supremo. De 1995 a 2003, porém, os Ministros Sepúlveda Pertence, Celso de Mello, Carlos Velloso e Marco Aurélio assinaram uma quantidade semelhante de Ofícios "PM-C" - uma média de 33 por mandato.

Como já referido, o Ministro Maurício Corrêa presidiu o Supremo Tribunal Federal por pouco mais de 11 meses, enquanto Nelson Jobim, seu sucessor, exerceu o mandato por quase 2 anos completos. Entre 2003 e 2004 , período que compreende 3 mandatos presidenciais, foram 30 comunicações ao Senado, número que não destoa da média bianual constatada desde 1995.

De 2005 em diante, por seu turno, provavelmente por consequência da entrada em

TABELA 3 - OFÍCIOS “PM-C" ENVIADOS POR CADA PRESIDENTE DO STF (1988-2016) TABLE 3 - OFÍCIOS “PM-C” SENT BY EACH CHIEF JUSTICE (1988-2016)

\begin{tabular}{|c|c|c|c|}
\hline Presidente da Corte & Ano & \multicolumn{2}{|c|}{$\begin{array}{l}\text { Ofícios } \\
\text { PM-C }\end{array}$} \\
\hline \multirow{2}{*}{ Rafael Mayer } & 1988 & 0 & \multirow{2}{*}{0} \\
\hline & 1989 & 0 & \\
\hline \multirow{3}{*}{ Néri da Silveira } & 1989 & 2 & \multirow{3}{*}{6} \\
\hline & 1990 & 3 & \\
\hline & 1991 & 1 & \\
\hline Aldir Passarinho & 1991 & 0 & 0 \\
\hline \multirow{2}{*}{ Sydney Sanches } & 1992 & 3 & \multirow{2}{*}{4} \\
\hline & 1993 & 1 & \\
\hline \multirow{2}{*}{ Octávio Gallotti } & 1993 & 7 & \multirow{2}{*}{11} \\
\hline & 1994 & 4 & \\
\hline \multirow{3}{*}{ Sepúlveda Pertence } & 1995 & 13 & \multirow{3}{*}{38} \\
\hline & 1996 & 18 & \\
\hline & 1997 & 7 & \\
\hline \multirow{3}{*}{ Celso de Mello } & 1997 & 14 & \multirow{3}{*}{32} \\
\hline & 1998 & 11 & \\
\hline & 1999 & 7 & \\
\hline \multirow{5}{*}{ Carlos Velloso } & 1999 & 11 & \multirow{5}{*}{29} \\
\hline & 2000 & 13 & \\
\hline & 2001 & 5 & \\
\hline & 2002 & 20 & \\
\hline & 2003 & 6 & \\
\hline
\end{tabular}

\begin{tabular}{|c|c|c|c|}
\hline Presidente da Corte & Ano & \multicolumn{2}{|c|}{$\begin{array}{l}\text { Ofícios } \\
\text { PM-C }\end{array}$} \\
\hline \multirow{3}{*}{ Marco Aurélio } & 2001 & 7 & 33 \\
\hline & 2002 & 20 & \\
\hline & 2003 & 6 & \\
\hline \multirow{2}{*}{ Maurício Corrêa } & 2003 & 5 & \multirow{2}{*}{9} \\
\hline & 2004 & 4 & \\
\hline \multirow{2}{*}{ Nelson Jobim } & 2004 & 15 & \multirow{2}{*}{22} \\
\hline & 2005 & 7 & \\
\hline \multirow{2}{*}{ Ellen Gracie } & 2006 & 7 & \multirow{2}{*}{11} \\
\hline & 2007 & 4 & \\
\hline \multirow{2}{*}{ Gilmar Mendes } & 2008 & 3 & \multirow{2}{*}{12} \\
\hline & 2009 & 9 & \\
\hline \multirow{2}{*}{ Cezar Peluso } & 2010 & 2 & \multirow{2}{*}{7} \\
\hline & 2011 & 5 & \\
\hline Ayres Britto & 2012 & 0 & 0 \\
\hline \multirow{2}{*}{ Joaquim Barbosa } & 2013 & 3 & \multirow{2}{*}{6} \\
\hline & 2014 & 3 & \\
\hline \multirow{3}{*}{ Ricardo Lewandowski } & 2014 & 10 & \multirow{3}{*}{20} \\
\hline & 2015 & 8 & \\
\hline & 2016 & 2 & \\
\hline \multirow[t]{2}{*}{ Carmen Lúcia } & \multirow[t]{2}{*}{2016} & \multirow[t]{2}{*}{1} & 1 \\
\hline & & & 241 \\
\hline
\end{tabular}

FONTE: Elaboração do autor. 
vigor da Emenda Constitucional 45/2004, o número médio de comunicações ao Senado por ano diminuiu. AMinistra Ellen Gracie e o Ministro Gilmar Mendes comunicaram, respectivamente, 11 e 12 acórdãos ao Senado durante seus mandatos presidenciais. Curiosamente, os dois Ministros-Presidentes seguintes, Cesar Peluso e Joaquim Barbosa, também assinaram um número aproximado, embora menor, de Ofícios "PM-C" - 7 e 6, respectivamente.

TABELA 4 - ESTADO DE TRAMITAÇÃO DOS OFÍCIOS “S” (OFS) (1988-2016) TABLE 4 - CURRENT PROCEDURAL STATE OF THE OFÍCIOS “S” (OFS) (1988-2016)

\begin{tabular}{|c|c|c|c|c|c|c|}
\hline \multirow{2}{*}{ Ano de recebimento do OFS } & \multicolumn{4}{|c|}{ Tramitação encerrada (decisão terminativa) } & \multirow{2}{*}{ Em trâmite } & \multirow{2}{*}{ Tota } \\
\hline & Rejeitado & Arquivado / Prejudicado & Transformado em PRS & Gerou RSF & & \\
\hline 1989 & & & 2 & 2 & & 2 \\
\hline 1990 & & 1 & 2 & 2 & & 3 \\
\hline 1991 & & & 1 & 1 & & 1 \\
\hline 1992 & & & 3 & 3 & & 3 \\
\hline 1993 & 1 & $3(*)$ & $5(*)$ & 4 & & 8 \\
\hline 1994 & & & 4 & 4 & & 4 \\
\hline 1995 & 1 & 7 & 5 & 5 & & 13 \\
\hline 1996 & & 12 & 6 & 6 & & 18 \\
\hline 1997 & & 11 & 9 & 9 & 1 & 21 \\
\hline 1998 & & 7 & 4 & 4 & & 11 \\
\hline 1999 & & 4 & 14 & 14 & & 18 \\
\hline 2000 & & 2 & 11 & 11 & & 13 \\
\hline 2001 & & $5\left(^{* *}\right)$ & $8\left({ }^{* *}\right)$ & 7 & & 12 \\
\hline 2002 & & 6 & 14 & 14 & & 20 \\
\hline 2003 & & 2 & 9 & 9 & & 11 \\
\hline 2004 & & 10 & 9 & 9 & & 19 \\
\hline 2005 & & 1 & 6 & 6 & & 7 \\
\hline 2006 & & 6 & 1 & 1 & & 7 \\
\hline 2007 & & 2 & 2 & 2 & & 4 \\
\hline 2008 & & 2 & 1 & 1 & & 3 \\
\hline 2009 & & 6 & 3 & 3 & & 9 \\
\hline 2010 & & 1 & 1 & 1 & & 2 \\
\hline 2011 & & & 5 & 5 & & 5 \\
\hline 2012 & & & & & & 0 \\
\hline 2013 & & & & & 3 & 3 \\
\hline 2014 & & & & & 13 & 13 \\
\hline 2015 & & 1 & 1 & 1 & 6 & 8 \\
\hline 2016 & & & & & 3 & 3 \\
\hline Total & 2 & 89 & 126 & 124 & 26 & 241 \\
\hline
\end{tabular}

(*) O OFS 122/1993 deu origem ao PRS 35/1995, mas foi arquivado em 1999 sem gerar RSF.

(**) O OFS 25/2001 deu origem ao PRS 26/2005, mas foi arquivado ao final da legislatura, em 2014 sem gerar RSF. FONTE: Elaboração do autor. 
constitucional pelo Supremo é um ato de natureza eminentemente política, de forma que o órgão legislativo pode decidir por não exercer sua competência privativa, ou seja, deixar de suspender a execução da lei declarada inconstitucional.

A tabela 4 classifica os Ofícios " $\mathrm{S}$ " de acordo com a última tramitação registrada em novembro de 2016. As informações foram retiradas do portal "Atividade Legislativa", integrante do sítio eletrônico do Senado Federal. Das 241 comunicações recebidas pela casa entre 1988 e 2016, 26 ainda não foram apreciadas e 215 tiveram sua tramitação encerrada.

Desses 215 Ofícios "S", dois foram rejeitados pelos senadores (o que corresponde a pouco mais de 0,8\% do total), 89 foram arquivados por perda de objeto (cerca de 36,9\% das comunicações) e 124 deram origem a Resolução do Senado que, efetivamente, suspendeu a execução dos dispositivos impugnados pelo Supremo Tribunal Federal - número que corresponde a mais de 51,4\% do total.

Nos dois casos em que a suspensão foi rejeitada, o senador relator do Ofício "S" na Comissão de Constituição, Justiça e Cidadania emitiu parecer favorável à suspensão do dispositivo, mas os membros daquela comissão rejeitaram o parecer. Em compensação, nos 89 casos em que o Ofício " $S$ " foi arquivado, o parecer do senador relator recomendava o arquivamento geralmente por ter o dispositivo impugnado já encontrado suspensão da execução, seja porque foi objeto de controle abstrato, súmula vinculante ou, mesmo, outra Resolução do Senado.
Veja-se que nesses casos não há uma vontade deliberada dos senadores em não suspender a execução da lei por entender que a declaração de inconstitucionalidade não deve operar com efeitos erga omnes, mas, ao contrário, porque já não é mais oportuno e conveniente tal suspensão por parte do Senado. Em outras palavras, a suspensão da execução pelo Senado não traria nenhum efeito prático.

A tabela 5 separa por objeto as 117 Resoluções do Senado que suspenderam a execução de lei declarada inconstitucional pelo Supremo entre 1988 e 2016. Dessas Resoluções, cinco tiveram por objeto a suspensão da execução de mais de uma norma, razão pela qual o número total de normas cuja execução foi suspensa (122) é maior que o número total de Resoluções editadas (117).

Da mesma forma, cinco Resoluções do Senado tiveram origem em mais de um Ofício "S", que tramitaram em conjunto, motivo pelo qual o número de Ofícios " $S$ " que geraram Resolução do Senado (124) é diverso do número total de Resoluções editadas (117).

É possível notar um equilíbrio entre a quantidade de normas federais (38), estaduais (49) e municipais (35) impugnadas - em relação ao total, correspondem a 31,15\%, $40,15 \%$ e $28,7 \%$, respectivamente. Postos os porcentuais em comparação com os dispositivos impugnados que deram origem aos Ofícios "PM-C", analisados pela tabela 2, eles se mostram bastante semelhantes - 36,5\%, $39,7 \%$ e $23,7 \%$, na ordem. 
TABELA 5 - RESOLUÇÕES DO SENADO (RSF) POR OBJETO (1988-2016) TABLE 5 - RESOLUTIONS OF THE SENATE (RSF) BY OBJECT (1988-2016)

\begin{tabular}{|c|c|c|c|c|c|c|c|c|}
\hline Âmbito & \multicolumn{2}{|c|}{ Federal } & \multicolumn{3}{|c|}{ Estadual } & \multicolumn{2}{|c|}{ Municipal } & \\
\hline Tipo & 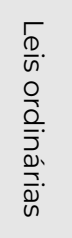 & 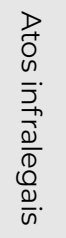 & 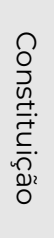 & 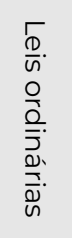 & $\begin{array}{l}D \\
D \\
0 \\
0 \\
\bar{n} . \\
\frac{D}{D} \\
\frac{0}{D} \\
\frac{0}{D} \\
\frac{0}{n} .\end{array}$ & 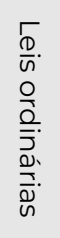 & $\begin{array}{l}D \\
D \\
0 \\
0 \\
\bar{J} \\
\stackrel{D}{0} \\
\frac{0}{D} \\
0 \\
0 \\
\frac{0}{n} .\end{array}$ & \\
\hline 1989 & 1 & & & & & & & 1 \\
\hline 1990 & & 1 & & 1 & & \multicolumn{2}{|l|}{1} & 3 \\
\hline 1993 & & & & 1 & & & & 1 \\
\hline 1995 & 7 & & & 3 & & 1 & & 11 \\
\hline 1996 & 2 & & & 2 & & 1 & & 5 \\
\hline 1997 & 1 & & & 2 & & & & 3 \\
\hline 1999 & 2 & 1 & & 2 & 1 & 5 & & 11 \\
\hline 2005 & $7(*)$ & 1 & 7 & 11 & 2 & 18 & $1(*)$ & 44 \\
\hline 2006 & $1(*)$ & $1\left(^{*}\right)$ & 1 & 1 & & 4 & & 7 \\
\hline 2007 & 4 & & 1 & 5 & 3 & 3 & & 16 \\
\hline 2008 & $2(*)$ & & & $2\left(^{*}\right)$ & 1 & & & 4 \\
\hline 2009 & & & & & 1 & & & 1 \\
\hline 2010 & & 2 & & 1 & & & & 3 \\
\hline 2012 & 2 & 1 & & 1 & & 1 & & 5 \\
\hline 2013 & & 1 & & & & & & 1 \\
\hline 2016 & 1 & & & & & & & 1 \\
\hline & 30 & 8 & 9 & 30 & 10 & 34 & 1 & 117 \\
\hline
\end{tabular}

(*) As RSF 9, 10 e 31/2005, 16/2006 e 7/2008 suspenderam mais de um diploma normativo cada. FONTE: Elaboração do autor.

A tabela 6 separa os Ofícios " $S$ " que tiveram sua tramitação encerrada antes de novembro de 2016 por tempo médio de apreciação pelo Senado, ou seja, o tempo aproximado entre o recebimento do Ofício "PM-C" e a decisão terminativa.

De 215 Ofícios "S", 121 - o que corresponde a $56,2 \%$ do total - encontraram decisão terminativa até três anos depois de terem sido recebidos pelo Senado, enquanto para os outros 94 - 43,8\% em relação ao todo - a decisão final foi tomada em tempo maior, mais de quatro anos após o registro de recebimento pelo Serviço de Protocolo da casa. 
TABELA 6 - TEMPO DE TRAMITAÇÃO FINAL DOS OFÍCIOS “S” (OFS) (1988-2016)

TABLE 6 - AVERAGE TIME OF FINAL DECISION ABOUT THE OFÍCIOS “S” (OFS) (1988-2016)

\begin{tabular}{lcccccccccccc}
\hline $\begin{array}{l}\text { Tempo aproximado } \\
\text { de apreciação dos } \\
\text { OFS (em anos) }\end{array}$ & $\mathbf{1}$ & $\mathbf{1}$ & $\mathbf{2}$ & $\mathbf{3}$ & $\mathbf{4}$ & $\mathbf{5}$ & $\mathbf{6}$ & $\mathbf{7}$ & $\mathbf{8}$ & $\mathbf{9}$ & $\mathbf{1 0}$ & $>\mathbf{1 0}$ \\
\hline Número de OFS & 25 & 40 & 34 & 22 & 13 & 24 & 13 & 12 & 10 & 4 & 5 & 13 \\
\hline & & & & & & & & & & & & \\
Porcentagem & $11,7 \%$ & $18,6 \%$ & $15,8 \%$ & $10,2 \%$ & $6,0 \%$ & $11,0 \%$ & $6,0 \%$ & $5,6 \%$ & $4,7 \%$ & $1,9 \%$ & $2,4 \%$ & $6,1 \%$
\end{tabular}

FONTE: Elaboração do autor.

O gráfico 1, por sua vez, coloca em um plano esse tempo médio de apreciação dos Ofícios " $\mathrm{S}$ ", classificando-os por ano de recebimento da comunicação.

Dos anos em que os Ofícios "S" têm a menor média de tempo entre o recebimento e a decisão terminativa (1989, 1990, 1994, 1995, 2005, 2007, 2008, 2009, 2010, 2011 e 2015), quatro deles correspondem aos anos em que mais foram editadas Resoluções do
Senado suspendendo a execução de lei inconstitucional (1995, com 11 RSF; 1999, com 11 RSF; 2005, com 44 RSF; e 2007, com 16 RSF).

Da mesma forma, dos anos em que os Ofícios " $\mathrm{S}$ " encontraram maior média de tempo de apreciação final (1991, 1996, 1997, 1998, 1999, 2000, 2001, 2006 e 2010), quatro deles correspondem àqueles que sequer houve Resolução do Senado editada para fins do art. 52, inc. X, da Constituição Federal (1991, 1998, 2000 e 2001).

GRÁFICO 1 - EVOLUÇÃO DO TEMPO MÉDIO DE APRECIAÇÃO DOS OFÍCIOS “S” PELO SENADO FEDERAL (1989-2016) GRAPH 1 - EVOLUTION OF THE AVERAGE TIME OF FEDERAL SENATE FIRST DECISION ABOUT THE “OFÍCIOS 'S'” (OFS) (1989-2016)

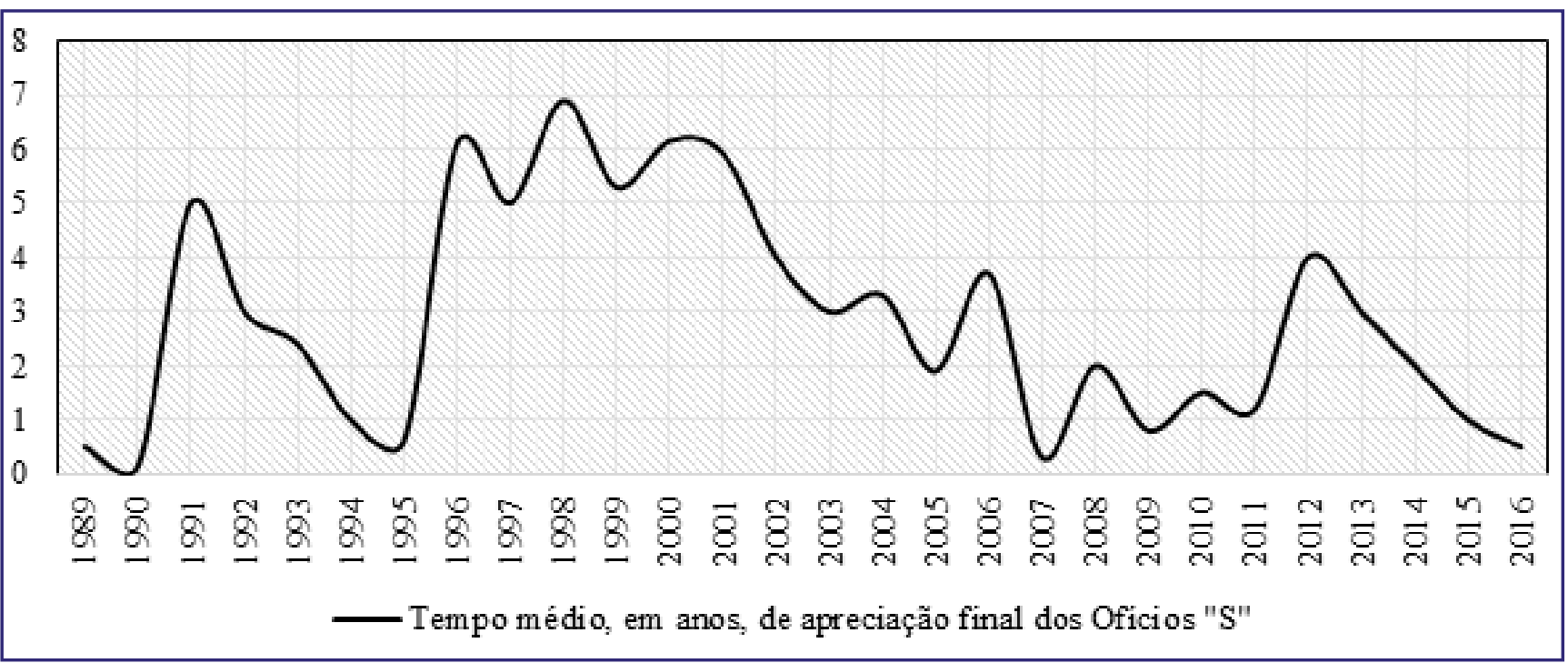

FONTE: Elaboração do autor. 


\section{CONCLUSÕES}

A partir da análise das tabelas e gráfico produzidos, é possível encontrar elementos para responder às questões elencadas no item 3.1. Primeiro, o Supremo Tribunal Federal comunica o Senado sobre as decisões tomadas, principalmente, em Ação Originária (AO), Habeas Corpus ( $\mathrm{HC}$ ), Mandado de Segurança (MS) e Recurso Extraordinário (RE) que tenham exercido controle difuso de constitucionalidade. Também foram levantadas comunicações que continham acórdãos de Ação Cível Originária (ACO), Agravo de Instrumento (AI), Inquérito (Inq), Reclamação (Rcl) e mesmo que por equívoco, Ação Direta de Inconstitucionalidade (ADI). Essas últimas classes processuais, porém, correspondem a pouco mais de $4 \%$ dos Ofícios "PM-C" encaminhados ao Senado Federal entre 1988 e 2016.

Segundo, foram comunicadas as decisões de inconstitucionalidade que fulminaram leis ordinárias e atos infralegais, de âmbito federal, estadual ou municipal. Em outras palavras, não houve restrição quanto ao objeto da decisão a ser comunicada. Pôde-se constatar, inclusive, um relativo equilíbrio entre a origem dos dispositivos impugnados, com leve predominância das normas de âmbito estadual.

Terceiro, não se pôde perceber uma uniformidade na quantidade de Ofícios "PM-C" encaminhados ano a ano ao Senado Federal, da mesma forma que não é possível exigir que o Supremo Tribunal Federal mantenha uma mesma média de declarações de inconstitucionalidade ano após ano. É certo que a frequência da comunicação de decisões de inconstitucionalidade variou no período pesquisado, mas essa variação não se mostrou significativa o suficiente de modo que se possa inferir uma ação deliberada por parte do signatário da comunicação - o Presidente da corte - que tenha dado causa a essa variação. Foi possível perceber, inclusive, uma diminuição na comunicação de decisões em Recurso Extraordinário (RE) a partir de 2005, após a instituição do requisito da repercussão geral, fato que acompanhou a diminuição, em paralelo, da própria quantidade de decisões em RE tomadas pela corte no mesmo período.

Desse modo, os elementos indicam que o Supremo Tribunal Federal efetivamente comunica ao Senado todas as decisões incidentais de inconstitucionalidade de sua lavra.

Recebidas as comunicações pelo Senado, constatou-se que mais da metade dos Ofícios " $\mathrm{S}$ " apreciados geram Resolução que suspende a execução de lei inconstitucional. Em outras palavras, o Senado Federal exerce a competência que Ihe foi conferida pelo art. 52, inc. $X$, da Constituição em mais de $51,4 \%$ dos casos. Além disso, o exercício dessa competência, ou seja, a decisão em suspender a execução da lei que foi declarada inconstitucional por decisão definitiva do Supremo não guarda relação com o tipo ou origem da norma impugnada. Ao contrário, demonstrou-se que a quantidade de normas federais, estaduais e municipais cuja execução foi suspensa é bastante próximo - 31,15\%, 40,15\% e 28,7\% em relação ao total, respectivamente.

Por outro lado, foi possível verificar que o elemento temporal foi o mais influente na decisão terminativa sobre os Ofícios " $\mathrm{S}$ ". $\mathrm{O}$ número de comunicações cuja tramitação encerrou menos de três anos após o recebimento pelo Serviço de Protocolo do Senado (121, 56,2\% do total) é bastante próximo ao 
número de Resoluções editadas no mesmo período (117). Da mesma forma, o número de comunicações rejeitadas e arquivadas por perda de objeto (91) não destoa da quantidade de Ofícios "S" cuja tramitação encerrou mais de quatro anos após o registro de recebimento pela casa legislativa.

Assim, é possível afirmar que os trabalhos da Comissão de Constituição, Justiça e Cidadania influenciam diretamente no exercício da competência prevista no art. 52, inc. X, da Constituição. É possível admitir, inclusive, que o Presidente da Comissão, responsável pela pauta, aja deliberadamente para que mais ou menos Ofícios " $\mathrm{S}$ " sejam apreciados em maior ou menor espaço de tempo, e assim mais ou menos leis declaradas inconstitucionais pelo Supremo Tribunal Federal tenham sua execução suspensa.

Essa constatação é bastante relevante, afinal, corrobora a conclusão esposada ao final da primeira parte do trabalho, segundo a qual o lapso temporal entre a decisão judicial e a atuação do Senado é elemento essencial para a compreensão do instituto. $O$ sistema foi concebido levando em conta a variável do tempo, legando ao órgão legislativo o condão de decidir politicamente, de acordo com a conveniência e a oportunidade de suspender a execução da lei neste ou naquele momento.

Seguindo essa linha de raciocínio, todas as outras conclusões dogmáticas passam a fazer maior sentido, seja a de que o Senado não encontra limites temporais legais para tomar sua decisão, seja a de que a suspensão da execução de lei inconstitucional opera automaticamente com eficácia prospectiva (ex nunc) e é definitiva. Obviamente há exceções, mas elas não maculam a lógica do sistema. Quanto à eficácia retroativa (ex tunc), ela é admitida quando o Senado a desejar e a registrar expressamente na redação da resolução suspensiva - e ocorre necessariamente nos casos já previstos no ordenamento jurídico, como os de supressão de normas penais em favor do réu. Quanto ao fato de que a suspensão é definitiva e não temporária, a Resolução do Senado apenas poderá ser anulada nas hipóteses em que o Supremo Tribunal Federal entenda haver inconstitucionalidade, como foi o caso da RSF 7/2007, quando o Senado equivocadamente suspendeu a execução de leis que não haviam sido objeto de declaração de inconstitucionalidade por parte do Supremo Tribunal Federal.

Por fim, convém registrar que a pesquisa empírica quantitativa, aliada à investigação de questões dogmáticas, permitiu demonstrar que o dispositivo do art. 52, inc. $X$, da Constituição Federal não é letra morta, nem sofreu mutação constitucional. Ao contrário, pôde-se perceber a importância do exercício dessa competência para o sistema de controle de constitucionalidade brasileiro e que sua compreensão não pode ser desvalorizada pela doutrina jurídica.

\section{REFERÊNCIAS}

Almeida, F. D. M. de A. (2007). Considerações sobre a função do Senado Federal de suspender execução de lei declarada inconstitucional pelo Supremo Tribunal. Revista de Informação Legislativa, 44 (174), 15-24.

Amaral Júnior, J. L. M. do. (2015). Controle de constitucionalidade: evolução brasileira determinada pela falta do stare decisis. In C. M. Clève. (Org.) Direito constitucional: processo constitucional (Tomo I, Vol. 10, pp. 41-55). São Paulo: Editora Revista dos Tribunais.

Barros, S. R. de. (2005). A função do Senado no controle de constitucionalidade. Cadernos de Direito, 5 (8-9), 139-155.

Barroso, L. R. (2012). O controle de constitucionalidade no direito brasileiro (6a ed.). São Paulo: Saraiva. 
Bastos, C. R. (1979). Curso de direito constitucional (2a ed.). São Paulo: Saraiva.

Bittencourt, C. A. L. (1968). O controle jurisdicional da constitucionalidade das leis (2a ed.). Rio de Janeiro: Forense.

Brasil. (1934). Constituição da República dos Estados Unidos do Brasil, de 16 de julho de 1934. Recuperado em 18 de fevereiro, 2017, de http://www.planalto.gov.br/ ccivil_03/Constituicao/Constituicao34.htm.

(1966). Supremo Tribunal Federal. Mandado de Segurança n. 16.512/DF. Relator: Ministro Oswaldo Trigueiro. Recuperado em 18 de fevereiro, 2017, de http://www.stf.jus.br/portal/jurisprudencia/listarJurisprudencia.asp?s1=\%28MS\%24\%2ESCLA \% $2 E+E+16512 \% 2 E N U M E 2 E \% 29+O U-$ $+\% 28 M S \% 2 E A C M S \% 2 E+A D J 2+16512 \% 2 E A-$ CMS\%2E\%29\&base=baseAcordaos\&url=http://tinyurl. com/aweybbs.

(1970). Resolução n. ${ }^{\circ}$ 73, de 1970. Regimento Interno do Senado Federal. Recuperado em 18 de fevereiro, 2017, de http://legis.senado.gov.br/legislacao/ ListaPublicacoes.action?id=102367\&tipoDocumento=RSF\&tipoTexto=ATU.

(1980). Regimento Interno do Supremo Tribunal Federal, de 27 de outubro de 1980. Recuperado em 18 de fevereiro, 2017, de http://www.stf.jus.br/arquivo/ cms/legislacaoRegimentolnterno/anexo/RISTF.pdf.

(1988). Constituição da República Federativa do Brasil, de 5 de outubro de 1988. Recuperado em 18 de fevereiro, 2017, de http://www.planalto.gov.br/ccivil_03/constituicao/constituicaocompilado.htm.

(1997). Decreto n. ${ }^{\circ}$ 2.346, de 10 de outubro de 1997. Recuperado em 18 de fevereiro, 2017, de http:// www.planalto.gov.br/ccivil_03/decreto/D2346.htm.

(1999). Lei n. 9.868, de 10 de novembro de 1999. Recuperado em 18 de fevereiro, 2017, de http://www. planalto.gov.br/ccivil_03/leis/L9868.htm.

(2007). Supremo Tribunal Federal. Medida Cautelar em Ação Direta de Inconstitucionalidade n. 3.929/DF. Relatora: Ministra Ellen Gracie. Recuperado em 18 de fevereiro, 2017, de http://www. stf.jus.br/portal/jurisprudencia/listarJurisprudencia. asp?s1=\%28ADI\%24\%2ECLA\%2E+E+3929\%2ENUME\%2E\%29+E+S\%2EPRES\%2E\&base=basePresidencia\&url=http://tinyurl.com/ctvu2tm.

(2014). Supremo Tribunal Federal. Reclamação n. ${ }^{\circ}$ 4.335/AC. Relator: Ministro Gilmar Mendes. Recuperado em 18 de fevereiro, 2017, de http://www.stf.jus.br/portal/jurispru-
dencia/listarJurisprudencia.asp?s7=\%28Rcl\%24\%2ESCLA\%2E + E + 4335\%2ENUME\%2E\%29+OU +\%28Rcl\%2EACMS\%2E+ADJ2+4335\%2EACMS\%2E\%29\&base=baseAcordaos\&url=http://tinyurl.com/c4z34zg. Brossard, P. (1967). O Senado e as leis inconstitucionais. Revista de Informação Legislativa, 13 (50), 55-64. Clève, C. M. (2000). A fiscalização abstrata da constitucionalidade no direito brasileiro (2a ed.). São Paulo: Editora Revista dos Tribunais.

Cooley, T. M. (1871). A treatise on the constitutional limitations which rest upon the legislative power of the states of the American Union (2nd ed.). Boston: Little, Brown \& Co. Recuperado em 18 de fevereiro, 2017, de http://repository.law.umich.edu/books/10/.

Estados Unidos. (1803). Supreme Court of United States. Marbury v. Madison. Chief Justice: John Marshall. 5 U.S. 137. Recuperado em 18 de fevereiro, 2017, de https://supreme.justia.com/cases/federal/us/5/137/case. html.

(1940). Supreme Court of United States. Chicot County Drainage Dist. v. Baxter State Bank. Chief Justice: Charles Evans Hughes. 308 U.S. 371. Recuperado em 18 de fevereiro, 2017, de https://supreme.justia. com/cases/federal/us/308/371/case.html.

Ferrari, R. M. M. N. (2004). Efeitos da declaração de inconstitucionalidade (5a ed.). São Paulo: Editora Revista dos Tribunais.

Ferraz, A. C. C. (2014). Comentários ao art. 52, X, da Constituição. In J. J. G. Canotilho, G. F. Mendes, I. W. Sarlet \& L. L. Streck (Coord.). Comentários à Constituição do Brasil (pp. 1060-1067). São Paulo: Saraiva/Almedina.

Mello, O. A. B. de. (1980). A teoria das constituições rígidas (2a ed.). São Paulo: José Bushatsky.

Mendes, G. F. (2008). O papel do Senado Federal no controle de constitucionalidade: um caso clássico de mutação constitucional. Revista de Informação Legislativa, 45 (179), 257-276.

; Branco, P. G. G. (2012). Curso de direito constitucional (7a ed.). São Paulo: Saraiva.

Mello Filho, J. C. de. (1986). Constituição Federal anotada (2a ed.). São Paulo: Saraiva.

Nery Júnior, N. (2010). O Senado Federal e o controle concreto de constitucionalidade de leis e de atos normativos: separação de poderes, Poder Legislativo e interpretação da CF 52 X. Revista de Informação Legislativa, 47 (187), 193-200.

Pedrón, F. Q. (2015). O julgamento da Reclamação n. ${ }^{\circ}$ 4.335-AC e o papel do Senado Federal no controle di- 
fuso de constitucionalidade. Revista de Informação Legislativa, 52 (207), 213-237.

Santos, C. V. N. dos. (2014). "Mutação à brasileira": uma análise empírica do art. 52, X, da Constituição. Revista Direito GV, 10 (2), 597-614. Recuperado em 18 de fevereiro, 2017, de http://direitosp.fgv.br/publicacoes/revista/artigo/mutacao-brasileira-analise-empirica-art52-x-constituicao.

Schauer, F. (2012). Precedent. In: A. Marmor. (Ed.). The Routledge Companion to Philosophy of Law (pp. 126136). New York: Routledge.

Silva, J. A. da. (1990). Curso de direito constitucional positivo (6a ed.). São Paulo: Editora Revista dos Tribunais.

(2002). Aplicabilidade das normas constitucionais (6a ed.). São Paulo: Malheiros.

(2014). Comentário contextual à Constituição (9a ed.). São Paulo: Malheiros.

Silva, P. N. N. da. (1992). A evolução do controle da constitucionalidade e a competência do Senado Federal. São Paulo: Editora Revista dos Tribunais.

Streck, L. L. (2014). Jurisdição constitucional e decisão jurídica (4a ed.). São Paulo: Editora Revista dos Tribunais.

Talamini, E. (2014). Efeitos da declaração de inconstitucionalidade. In C. M. CLÈVE (Coord.). Direito constitucional brasileiro: organização do Estado e dos poderes (Vol. 2, pp. 669-705). São Paulo: Editora Revista dos Tribunais.

Temer, M. (2004). Elementos de direito constitucional (19a ed.). São Paulo: Malheiros.

Data de submissão: 14/03/2017

Data de aceite: 28/09/2017 